\title{
Pendekatan Manajemen dalam Pengkajian Islam
}

\author{
Rifki Ahda Sumantri, Ahmad Yusuf Prasetiawan, Musmuallim \\ Universitas Jenderal Soedirman \\ rifki.sumantri@unsoed.ac.id
}

\begin{abstract}
This paper discussed the concept of management in Islam, definitions, roles, functions, and various matters related to management in Islamic studies. This study is a qualitative and library research. The data has been analized by the descriptive method. The result showed that the purpose of management is the implementation of the entire work program effectively and efficiently. Effective means achieving goals, while efficient in the general sense means saving. So, there are two main objectives with the implementation of management in the completion of work, organization, institutions and institutions. If we examine and understand the contents and meaning contained in the verses of the Quran or the Hadith of the Prophet, also contained in the kitab kuning, there will be many teachings are actually the principles and fundamentals of management. In the history of Islam the first period we know that among the companions of the Prophet there was a person who lay the foundation of the administration of Islamic government, namely Caliph Umar Ibn Khattab. He is considered a genius in laying the foundation of Islamic government. During the Islamic government was an efficient government. Islam views management as a tool that can be used to implement what is in the Koran and Hadith, it is not surprising that management is used as a scientific discipline to approach Islamic studies. The approach then produces a very extraordinary finding, management turns out to be able to provide answers that are both theoretical and practical.
\end{abstract}

Keywords: approach; management; Islamic studies

Abstrak: Tulisan ini membahas tentang manajemen di dalam Islam, definisi,
peranan, fungsi, dan berbagai hal yang berkaitan dengan manajemen dalam
pengkajian Islam. Penelitian ini merupakan penelitian kualitatif dan merupakan
penelitian kepustakaan. Metode analisis data yang digunakan adalah metode
deskriptif. Hasil penelitian menunjukkan bahwa tujuan manajemen adalah
terselenggaranya keseluruhan program kerja secara efektif dan efisien. Efektif
berarti mencapi tujuan, sedangkan efisien dalam arti umum berarti hemat. Jadi,
ada dua tujuan pokok dengan diterapkannya manajemen dalam suatu
penyelesaian pekerjaan, organisasi, isntansi dan lembaga. Jika kita meneliti dan
memahami isi dan makna yang terkandung di dalam ayat-ayat al-Quran atau
Hadis, juga yang terkandung di dalam kitab kuning maka akan terdapat banyak
ajaran yang sebenarnya adalah prinsip-prinsip dan dasar-dasar manajemen.
Dalam sejarah Islam periode pertama kita ketahui diantara sahabat-sahabat Nabi
ada seorang yang merupakan peletak dasar administrasi pemerintahan Islam yaitu
Khalifah Umar Ibnu Khattab. Beliau dianggap sebagai seorang yang genius dalam
meletakkan dasar pemerintahan Islam. Pada masa pemerintahan Islam merupakan
pemerintahan yang efisien. Islam memandang manajemen sebagai sebuah alat
yang dapat digunakan untuk mengimplementasikan apa yang ada di dalam al- 
Quran dan Hadis, tidak heran bahwa manajemen digunakan sebagai disiplin ilmu untuk mendekati kajian Islam. Pendekatan tersebut kemudian menghasilkan temuan yang sangat luar biasa, manajemen ternyata mampu memberikan jawaban baik yang bersifat teori ataupun praktis.

Kata kunci: pendekatan; manajemen; pengkajian Islam

\section{A. Pendahuluan}

Manajemen sebagai ilmu yang baru dikenal pada pertengahan abad ke-19, dewasa ini sangat populer, bahkan dianggap sebagai kunci keberhasilan pengelolaan masyarakat atau perusahaan, baik perusahaan yang bertujuan mengejar keuntungan maupun yang berfungsi sosial saja. Bahkan ada orang yang menganggap manajemen sebagai suatu "ciri" dari masyarakat modern. Karena adanya manajemen masyarakat akan berkembang dan perusahaan diharapkan akan berhasil. Pandangan ini juga telah memasuki negeri-negeri Islam, bahkan telah menjadi "mode" untuk berlomba-lomba mempelajari manajemen, baik sebagai salah satu mata pelajaran yang berdiri sendiri di perguruan tinggi, juga telah menjadi topik-topik aktual dalam seminar ataupun dalam kursus-kursus singkat pendidikan ${ }^{1}$.

Dengan pengetahuan manajemen, kita bisa mengangkat dan menerapkan prinsipprinsip dasar serta ilmu yang ada di dalam al-Quran dan Hadis, yang sebenarnya merupakan dasar-dasar dan pokok-pokok ilmu manajemen pula. Makin luas ilmu-ilmu modern itu kita kuasai, makin banyak pula rahasia yang terkandung di dalam ajaran Islam yang dapat kita buka dan kita angkat kepermukaan, serta kita terapkan dalam kenyataan yang hidup di masyarakat yang selalu berkembang ${ }^{2}$. Istilah manajemen mengacu kepada proses pelaksanaan aktivitas yang diselesaikan secara efisien dengan dan melalui pendayagunaan orang lain, yang bermuara kepada pencapaian tujuan bersama ${ }^{3}$.

Makalah ini memperbincangkan konsep manajemen di dalam Islam, baik definisi, peranan, fungsi, dan berbagai hal yang berkaitan dengan manajemen dalam pengkajian Islam. Penelitian ini merupakan penelitian kualitatif dan merupakan penelitian kepustakaan. Sumber data berasal dari dokumentasi naskah kepustakaan yang dianalisis dengan menggunakan metode deskriptif.

\section{B. Definisi Manajemen}

Kata manajemen berasal dari bahasa Latin, yaitu dari asal kata manus yang berarti tangan dan agere yang berarti melakukan. Kata-kata itu digabung menjadi kata kerja managere yang artinya menangani. Managere diterjemahkan ke dalam bahasa Inggris dalam bentuk kata kerja to manage, dengan kata benda management, dan manager untuk orang yang melakukan kegiatan manajemen. Akhirnya, management diterjemahkan ke dalam Bahasa Indonesia menjadi manajemen atau pengelolaan. Manajemen menurut Parker ialah seni melaksanakan suatu pekerjaan melalui orang-orang (the art of getting things done

\footnotetext{
${ }^{1}$ Mochtar Effendy, Manajemen: Suatu Pendekatan Berdasarkan Ajaran Islam (Jakarta: Bhratara Karya Aksara, 1986), p. 5.

${ }^{2}$ Mochtar Effendy, p. 5.

${ }^{3}$ Marno dan Triyo Supriyatno, Manajemen dan Kepemimpinan Pendidikan Islam (Bandung: Refika Aditama, 2008), p. 1.
} 
through people). ${ }^{4}$

Menurut Dimock, manajemen adalah mengetahui kemana yang dituju, kesukaran apa yang harus dihindari, kekuatan apa yang harus dijalankan dan bagaimana mengemudikan kapal Anda serta anggota dengan sebaik-baiknya tanpa pemborosan waktu dalam proses mengerjakannya. Kemudian Stooner berpendapat bahwa manajemen adalah proses perencanaan, pengorganisasian, pengarahan, dan pengawasan usaha-usaha para anggota organisasi dan pengguna sumber daya-sumber daya organisasi lainnya agar dapat mencapai tujuan organisasi yang ditetapkan. Sedangkan menurut Sondang Palan Siagian, manajemen adalah keseluruhan proses kerjasama antara dua orang atau lebih yang didasarkan atas rasionalitas tertentu untuk mencapai tujuan yang ditentukan sebelumnya. ${ }^{5}$

Nanang Fattah berpendapat bahwa manajemen adalah proses merencana, mengorganisasi, memimpin dan mengendalikan upaya organisasi dengan segala aspeknya agar tujuan organisasi tercapai secara efektif dan efisien. Menurut Oemar Hamalik, manajemen adalah sebuah proses sosial yang berkenaan dengan keseluruhan usaha manusia dengan bantuan manusia lain serta sumber-sumber lainnya, menggunakan metode yang efisien dan efektif untuk mencapai tujuan yang ditentukan sebelumnya. ${ }^{6}$

Manajemen adalah kebiasaan yang dilakukan secara sadar dan terus-menerus dalam dalam membentuk organisasi. ${ }^{7}$ Definisi manajemen menurut E.F.L. Brech merupakan kegiatan untuk menyelesaikan pekerjaan yang fungsinya membuat perencanaan dan memberikan pengarahan bagaimana penyelesaian tugas itu harus dilakukan. ${ }^{8}$

Manajemen menurut George R. Terry adalah sebuah proses yang khas, yang terdiri dari tindakan-tindakan: perencanaan, pengorganisasian, menggerakkan dan pengawasan yang dilakukan untuk menentukan serta mencapai sasaran-sasaran yang telah ditetapkan melalui pemanfaatan sumber daya manusia serta sumber-sumber lain. ${ }^{9}$ Manajemen menurut David. H. Holt adalah proses merencanakan, mengorganisasi, dan mengendalikan yang mencakup manusia, material, dan sumber daya keuangan dalam suatu lingkungan organisasi. $^{10}$

Dari beberapa definisi manajemen yang telah disajikan, pengertian manajemen secara garis besar adalah proses perencanaan, pengorganisasian, pengarahan, dan pengendalian sumber daya organisasi untuk mencapai tujuan secara efektif dan efisien. Efektifitas dan efisiensi tujuan sangat diperlukan oleh sebuah organisasi. Hal ini sangat beralasan karena dengan adanya hal tersebut diharapkan organisasi akan cenderung memiliki dinamisasi dan tidak statis dengan keadaan yang ada. Peran serta seorang manajer sangat vital di dalam mengelola suatu organisasi tertentu baik secara langsung atau tidak langsung.

\footnotetext{
${ }^{4}$ Husaini Usman, Manajemen: Teori. Praktik, dan Riset Pendidikan (Jakarta: Bumi Aksara, 2011), p. 5.

${ }^{5}$ Sulistyorini, Manajemen Pendidikan Islam: Konsep, Strategi dan Aplikasi (Yogyakarta: Teras, 2009), p. 11.

${ }^{6}$ Baharuddin dan Moh. Makin, Manajemen Pendidikan Islam: Transformasi Menuju Sekolah/Madrasah Unggul (Malang: UIN Maliki Press, 2010), p. 49.

${ }^{7}$ Freeman Stoner dan Gilbert, Manajemen (Jakarta: Prenhallindo, 1996), p. 7.

${ }^{8}$ Ibnu Syamsi, Pokok-Pokok Organisasi dan Manajemen (Jakarta: Rineka Cipta, 1994), p. 59.

${ }^{9}$ Uhar Suharsaputra, Administrasi Pendidikan (Bandung: Refika Aditama, 2010), p. 6.

${ }^{10}$ Amin Widjaja Tunggal, Manajemen Suatu Pengantar (Jakarta: Rineka Cipta, 2002), p. 31.
} 


\section{Fungsi-Fungsi Manajemen}

Sama halnya dengan pengertian manajemen, fungsi-fungsi manajemen pun banyak tokoh dan pakar manajemen yang membagi menjadi beberapa bagian. Dari beberapa pendapat para tokoh mengalami beberapa perbedaan, hal tersebut disebabkan oleh cara pandang dan logika berpikir yang dikemukakan oleh masing-masing tokoh. Bukan tanpa alasan, pastinya mereka memiliki alasan tertentu mengapa berpendapat seperti itu.

Fungsi-fungsi manajemen memiliki peranan yang sentral terhadap keberadaan suatu organisasi, jika fungsi-fungsi manajemen tidak berjalan baik maka akan berimplikasi terhadap kualitas organisasi yang nantinya akan berpengaruh terhadap kuantitas yang telah dimiliki. Tapi, jika fungsi-fungsi manajemen berjalan dengan baik maka akan berimbas terhadap pencapain tujuan yang telah ditetapkan sebelumnya. Dengan demikian dapat disimpulkan bahwa begitu pentingnya fungsi-fungsi manajemen di dalam suatu organisasi.

Menurut Hendri Fayol fungsi-fungsi manajemen terdiri dari perencanaan, pengorganisasian, pemberian perintah, pengkoordinasian, dan pengendalian. Klasifikasi ini ini merupakan awal munculnya dari berbagai fungsi-fungsi manajerial yang ada. ${ }^{11}$ Luther Gullick mengemukakan bahwa fungsi manajemen terdiri dari planning, organizing, staffing, directing, coordinating, reporting and budgeting. ${ }^{12}$

George R. Terry mengklasifikasikan fungsi manajemen menjadi empat macam yaitu perencanaan, pengorganisasian, pelaksanaan dan pengendalian. Sementara itu, James Stoner juga mengklasifikasikan fungsi manajemen menjadi empat, yaitu perencanaan, pengorganisasian, memimpin dan pengendalian. Di antara tokoh di atas yang paling banyak mengklasifikasikan fungsi manajemen adalah Luther Gullick. Perbedaan fungsi-fungsi manajemen diatas terdapat pada fungsi pemberian perintah, penyusunan pekerja (staffing), pengarahan, penyusunan laporan, pelaksanaan dan memimpin. Dari perbedaan itu juga terdapat kesamaan yaitu pada fungsi perencanaan, pengorganisasian, koordinasi dan pengendalian. ${ }^{13}$ Adapun fungsi pokok manajemen diuraikan sebagai berikut.

\section{Planning (Perencanaan)}

Perencanaan merupakan suatu pondasi dalam sebuah organisasi. Perencanaan memberikan gambaran dan rancangan terhadap apa yang akan ditempuh dan apa yang akan dicapai. Dengan adanya perencanaan maka diharapkan suatu organisasi dapat menjalankan aktivitas yang sesuai dengan program yang telah ditetapkan dan disusun sebelumnya. Efektifitas dan efisiensi dalam pencapaian dapat diukur melalui perencanaan yang matang dan berkesinambungan.

Harold Koonzt dan Cyrill O'Donnel mengatakan bahwa perencanaan sebagai persiapan yang teratur dari setiap usaha yang mewujudkan/mencapai tujuan atau tujuantujuan yang telah ditentukan. Jadi, dalam sebuah perencanaan telah terancang langkahlangkah yang jelas bagaimana mencapai tujuan yang telah ditetapkan. ${ }^{14}$ Menurut G. R. Terry perencanaan adalah menetapkan pekerjaan yang harus dilaksanakan oleh kelompok untuk

\footnotetext{
${ }^{11}$ Marno dan Triyo Supriyatno, p. 11.

${ }^{12}$ Manullang, Dasar-Dasar Manajemen (Yogyakarta: Gadjah Mada University Press, 2005), p. 7.

${ }^{13}$ Manullang, p. 7.

${ }^{14}$ Suwarto, Perilaku Keorganisasian. (Yogyakarta: Atmajaya Press, 1999), p. 67.
} 
mencapai tujuan yang digariskan. ${ }^{15}$ Perencanaan menurut Prajudi Atmosudirjo adalah perhitungan dan penentuan tentang sesuatu yang akan dijalankan dalam rangka mencapai tujuan tertentu, siapa yang melakukan, bilamana, dimana, dan bagaimana cara melakukannya. ${ }^{16}$

Perencanaan yang baik menurut Siagian adalah: 1) Rencana harus dapat mempermudah tercapainya tujuan yang ditentukan; 2) Perencanaan yang dilakukan benarbenar memahami hakekat tujuan yang ingin dicapai; 3) Pemenuhan persyaratan keahlian teknis; 4) Rencana disertai oleh rincian yang cermat; 5) Keterkaitan rencana dengan pelaksanaan; 6) Kesederhanaan; 7) Fleksibelitas; 8) Rencana memberikan tempat pada pengambilan resiko; 9) Rencana yang pragmatis; 10) Rencana sebagai instrumen peramalan masa depan. ${ }^{17}$ Perencanaan yang baik akan mempermudah dan memberikan arah yang jelas terhadap tujuan organisasi. Kesepuluh poin diatas memberikan gambaran bahwa perencanaan dicapai bukan dengan cara yang sembarangan dan asal-asalan. Akan tetapi, perencanaan menggunakan cara-cara dan perlakuan yang baik dan cermat. Jika perencanaan dilakukan dengan cara yang sembarangan maka eksistensi organisasi dapat goyah dan berpotensi untuk hancur atau bahkan bubar di tengah jalan. Dengan demikian, eksistensi suatu organisasi dapat diukur dengan menggunakan parencanaan yang baik.

\section{Organizing (Pengorganisasian)}

Pengorganisasian merupakan aspek dari fungsi manajemen yang tidak kalah pentingnya dengan perencanaan. Keterkaitan antara perencanaan dan pengorganisasian membuat kedua hal tersebut tak dapat dipisahkan satu sama lain, mengapa demikian karena kedua hal tersebut merupakan aspek yang saling mendukung dan merupakan fungsi manajemen setelah adanya sistem perencanaan. Pengorganisasian merupakan sebuah sistem yang ada dan berkembang di dalam organisasi, baik langsung ataupun tidak langsung ataupun dalam skala kecil maupun skala besar. Menurut G. R. Terry pengorganisasian merupakan kegiatan yang dilakukan untuk menghimpun dan menyusun semua sumber terutama sumber daya manusia sehingga kegiatan yang dilakukan dapat berjalan dengan efektif dan efisien. ${ }^{18}$

Pengorganisasian menurut Pierce I dan Robinson adalah proses menentukan hubungan-hubungan yang esensial diantara orang-orang, tugas-tugas, aktivitas-aktivitas dengan cara mengintegrasikan dan mengkordinasikan semua sumber organisasi ke arah pencapaian suatu tujuan secara efektif dan efisien. ${ }^{19}$ Dalam pengorganisasian dapat disimpulkan bahwa terdapat adanya kegiatan seperti penyusunan dan penghimpunan terhadap sumber daya yang diperlukan. Di dalamnya juga terdapat adanya pembagian tugas, tanggung jawab dan wewenang yang diatur sebagai wahana pencapaian organisasi. Proses pengorganisasian digunakan untuk memberikan acuan terhadap pemanfaatan dan pengelolaan sumber daya manusia, dan diharapkan manusia yang ada di dalam organisasi

\footnotetext{
${ }^{15}$ George R. Terry, Asas-Asas Manajemen (Bandung: Alumni, 2006), p. 17.

${ }^{16}$ Husaini Usman, p. 65.

${ }^{17}$ Sondang P. Siagian, Teori Pengembangan Organisasi (Jakarta: Bumi Aksara, 2007), p. 34.

${ }^{18}$ Sudjana, Manajemen Program Pendidikan untuk Pendidikan Nonformal dan Pengembangan Sumber Daya Manusia (Bandung: Falah, 2004), p. 106.

${ }^{19}$ Marno dan Triyo Supriyatno, p. 16.
} 
dapat menggali sumber daya lainnya. Sumber daya manusia sangat berpengaruh terhadap proses pengorganisasian, hal tersebut dapat memberikan nuansa yang berbeda terhadap arah, kondisi, dan pencapaian target tujuan organisasi yang telah disusun sebelumnya.

\section{Actuating (Pelaksanaan)}

Setelah adanya perencanaan dan pengorganisasian maka hal yang harus dilakukan adalah kegiatan pelaksanaan. Kegiatan pelaksanaan ini adalah proses tindak lanjut dari serangkaian aktivitas yang telah disusun atau dirancang sebelumnya setelah adanya klasifikasi dari sisi kompetensi, tugas dan wewenang serta tanggung jawab. Actuating merupakan proses yang tidak hanya menggerakan orang atau personil tetapi juga untuk memberikan motivasi kepada personil yang berguna untuk kelangsungan organisasi. Menurut G. R. Terry dalam bukunya Asas-Asas Manajemen mengemukakan bahwa actuating merupakan usaha manajer untuk menggerakkan para anggota agar mereka memiliki keinginan dan berusaha untuk mencapai sasaran-sasaran perusahaan. ${ }^{20}$

Sedangkan Koonzt dan Cryill O’Donnel berpendapat bahwa Actuating merupakan hubungan antara aspek-aspek individual yang yang ditimbulkan oleh adanya hubungan terhadap bawahan untuk dapat mengerti dan memahami pembagian pekerjaan yang efektif dan efisien. ${ }^{21}$ Berdasarkan pemahaman definisi di atas, dapat disebutkan bahwa proses actuating merupakan proses yang sangat penting karena di aspek ini bersentuhan langsung dengan orang-orang yang ada di dalam organisasi. Dalam proses ini merupakan tantangan awal bagi seorang manajer karena diakui ataupun tidak orang-orang yang berada dalam lingkungan organisasinya tidak semuanya mudah dan gampang diatur. Kesimpulannya adalah tidak semudah membalikan kedua telapak tangan.

\section{Controlling (Pengendalian atau Pengawasan)}

Dalam sebuah organisasi memerlukan gambaran terhadap seluruh program yang diinginkan dapat tercapai, maka diperlukan suatu metode yang harus dilaksanakan agar semua aspek dapat sesuai dengan tugas dan wewenang masing-masing. Ada beberapa cara yang biasa digunakan dalam sebuah organisasi, yang telah familier kita tahu adalah pengawasan/pengendalian atau controlling. Pengawasan bertujuan untuk mengawal dan memastikan arah tujuan organisasi telah berjalan dengan baik dan benar, jika ada sesuatu yang janggal maka harus dilakukan tindakan.

Pengendalian juga bertujuan untuk meminimalisir penyimpangan dan penyalahgunaan serta mencari kelemahan yang ada di dalam organisasi. Dengan adanya pengendalian, jika hasilnya diketahui ada sesuatu yang tidak benar maka bisa segera melakukan evaluasi dan mencari solusi terbaik untuk menanggulangi masalah tersebut dan diharapkan kelemahan yang ada di dalam organisasi tersebut dapat dijadikan sebagai wahana dan batu loncatan agar lebih baik.

Pengendalian menurut G. R. Terry adalah suatu usaha untuk meneliti kegiatankegiatan yang telah dan yang akan dilaksanakan. Pengendalian berorientasi pada objek yang dituju dan merupakan alat untuk menyuruh orang-orang bekerja menuju sasaran yang ingin

\footnotetext{
${ }^{20}$ George R. Terry, p. 313.

${ }^{21}$ Baharuddin dan Moh. Makin, p. 105-106.
} 
dicapai. ${ }^{22}$ Pengendalian menurut Sarwoto adalah kegiatan manajer yang mengusahakan agar pekerjaan-pekerjaan terlaksana sesuai dengan rencana yang ditetapkan atau hasil yang dikehendaki. Ini berarti bahwa betapapun baiknya perencanaan, akan bisa gagal apabila manager tidak melakukan pengawasan. ${ }^{23}$

Inti dari adanya pengawasan adalah untuk memungkinkan adanya pembenahan dan evaluasi terhadap kinerja yang ada. Jika kinerjanya buruk maka pantas untuk dilakukan evaluasi dan pertimbangan untuk mengambil keputusan. Adanya fungsi ini diharapkan akan memunculkan umpan balik (feedback) terhadap seluruh kinerja yang dilakukan sehingga akan ditemukan beberapa kelemahan atau kekurangan untuk kemudian dilakukan koreksi seperlunya.

\section{Tujuan Manajemen}

Tujuan manajemen adalah terselenggaranya keseluruhan program kerja secara efektif dan efisien. Efektif berarti mencapi tujuan, sedangkan efisien dalam arti umum berarti hemat. Jadi, ada dua tujuan pokok dengan diterapkannya manajemen dalam suatu penyelesaian pekerjaan, organisasi, isntansi dan lembaga. Menurut Nanang Fattah tujuan manajemen adalah untuk memperoleh produktivitas dan kepuasan. Inti dari manajemen dapat diungkapkan sebagai pencapaian tujuan secara optimal dengan menggunakan sumber daya yang dimiliki. Jika dilihat secara sederhana, maka adanya tujuan manajemen dimaksudkan untuk memberikan motivasi atau dorongan terhadap pekerjaan dan kinerja seseorang sehingga tujuan terbentuknya organisasi dapat tercapai dan memunculkan rasa kepuasan bagi pendiri, pelaku dan pengguna organisasi. ${ }^{24}$

Menurut Ibrahim Bafadal tujuan manajemen adalah: 1) Efektifitas, tujuan manajemen itu diupayakan dalam rangka mencapai efektifitas. Suatu program kerja dikatakan efektif apabila program kerja tersebut dapat mencapai tujuan yang telah ditetapkan sebelumnya. Dengan kata lain, tujuan ditetapkannya manajemen pada sebuah program adalah program tersebut dapat mencapai tujuan. 2) Manajemen dilakukan dalam rangka mencapai efisiensi pelaksanaan setiap program. Efisiensi merupakan suatu perbandingan konsepsi antara perbandingan pelaksanaan satu program dengan hasil akhir yang diraih atau dicapai. ${ }^{25}$

Hal-hal yang harus diperhatikan dalam mewujudkan tujuan agar dapat terlaksana dengan baik adalah: 1) Tujuan harus jelas dan berdasarkan analisis data dan potensi yang dimiliki; 2) Tujuan dirumuskan dengan melibatkan karyawan; 3) Sub-sub tujuan yang dibentuk harus menunjang terhadap pencapaian tujuan organisasi; 4) Tujuan harus mempunyai jangkauan dan memberikan kepuasan bagi karyawan; 5) Tujuan harus realistis dan masuk akal; 6) Tujuan bersifat kontemporer dan inovatif; 7) Tujuan yang ditetapkan sesuai dengan kemampuan pelaksana; 8) Tujuan disesuaikan atau diurutkan sesuai dengan

${ }^{22}$ Marno dan Triyo Supriyatno, p. 24.

${ }^{23}$ Baharuddin dan Moh. Makin, p. 111.

${ }^{24}$ Nanang Fattah, Landasan Manajemen Pendidikan (Bandung: Remaja Rosdakarya, 2006), p. 15.

${ }^{25}$ Ibrahim Bafadal, Manajemen Peningkatan Mutu Sekolah Dasar dari Sentralisasi Menuju Desentralisasi (Jakarta: Bumi Aksara, 2003), p. 50. 
kepentingannya; dan 9) Aneka tujuan yang dibentuk harus berimbang. ${ }^{26}$

\section{E. Pendekatan Manajemen dalam Kajian Islam}

Pada dasarnya, tidak ada pembagian yang kaku yang bersifat dikotomis antara manajemen Islam dan manajemen umum. Hanya saja karena manajemen muncul sebagai sebuah proses kegiatan dimana seseorang melakukannya untuk mencapai tujuan, maka manejemen Islam dimaknai sebagai sebuah proses manajerial atau konsep (prinsip) yang dijalankan sebagai kegiatan seseorang yang sesuai dengan nilai-nilai Islam. ${ }^{27}$

Manajemen yang baik dalam Islam adalah yang konsep serta tujuannya didasarkan pada nilai-nilai ajaran Islam. Contoh nyata bahwa Islam memberikan konsep manajemen tergambar dalam aktivitas salat. Islam memberikan gambaran tentang bagaimana konsep manajemen bisa mengadopsi tertib dan disiplinnya umat Islam ketika melaksanakan salat lima waktu. Tertib, karena sholat lima waktu telah ditentukan urutannya untuk dilaksanakan. Disiplin, karena umat Islam diperintahkan untuk tidak keluar dari waktu-waktu tersebut dan bisa melaksanakan di awal waktu. ${ }^{28}$

Jauh sebelum Frederick W. Taylor dan Henry Fayol mengangkat prinsip manajemen sebagai suatu ilmu di dalam ajaran al-Quran dan Hadis, sudah terdapat pokok-pokok dan prinsip-prinsip manajemen yang jika diperbandingkan dengan dasar-dasar atau prinsipprinsip yang ada di dalam buku-buku standar manajemen sekarang tidaklah kurang berbobot, karena ajaran itu merupakan prinsip-prinsip dan dasar-dasar manajemen juga sekalipun dengan istilah lain. Jika kita meneliti dan memahami isi dan makna yang terkandung di dalam ayat-ayat al-Quran atau Hadis Nabi, juga yang terkandung di dalam kitab "kuning" kitab-kitab muamalat, serta di ajaran akhlak (etika) atau tasawuf Islam, maka akan terdapat banyak ajaran yang sebenarnya adalah prinsip-prinsip dan dasar-dasar manajemen. Dalam sejarah Islam periode pertama kita ketahui diantara sahabat-sahabat Nabi ada seorang yang merupakan peletak dasar administrasi pemerintahan Islam yaitu Khalifah Umar Ibnu Khattab. Beliau dianggap sebagai seorang yang genius dalam meletakkan dasar pemerintahan Islam. Pada masa pemerintahan Islam merupakan pemerintahan yang efisien. $^{29}$

Manajemen berhubungan dengan masalah tanggung jawab, pembagian kerja, efisiensi dan lain sebagainya. Di bawah ini penulis sajikan potongan ayat al-Quran yang berkaitan dengan manajemen. Kewajiban bertanggung jawab di dalam Islam:



Barangsiapa yang mengerjakan kebaikan seberat dzarrahpun, niscaya Dia akan melihat (balasan)nya. Dan Barangsiapa yang mengerjakan kejahatan sebesar dzarrahpun, niscaya Dia akan melihat (balasan)nya pula. (QS. az-Zalzalah/99: 7-8).

${ }^{26}$ Malayu Hasibuan, Manajemen: Dasar, Pengertian dan Masalah (Jakarta: Bumi Aksara, 2006), p. 20.

${ }^{27}$ Fathul Aminudin Aziz, Manajemen dalam Perspektif Islam (Cilacap: Pustaka El Bayan, 2017), p. 24.

${ }^{28}$ Mohamed Branine and David Pollard, 'Human resource management with Islamic management principles: A dialectic for a reverse diffusion in management', Personnel Review, 39.6 (2010), $712-727$.

${ }^{29}$ Mochtar Effendy, p. 8-9. 


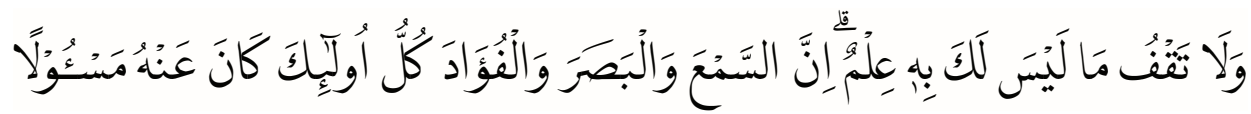

Dan janganlah kamu mengikuti apa yang kamu tidak mempunyai pengetahuan tentangnya. Sesungguhnya pendengaran, penglihatan dan hati, semuanya itu akan diminta pertanggungan jawabnya. (QS. al-Isra'/17: 36).

Mengenai pembagian kerja Allah berfirman:



Dan Dia lah yang menjadikan kamu penguasa-penguasa di bumi dan Dia meninggikan sebahagian kamu atas sebahagian (yang lain) beberapa derajat, untuk mengujimu tentang apa yang diberikan-Nya kepadamu. Sesungguhnya Tuhanmu amat cepat siksaan-Nya dan Sesungguhnya Dia Maha Pengampun lagi Maha Penyayang. (QS. al-An'am/6: 165).

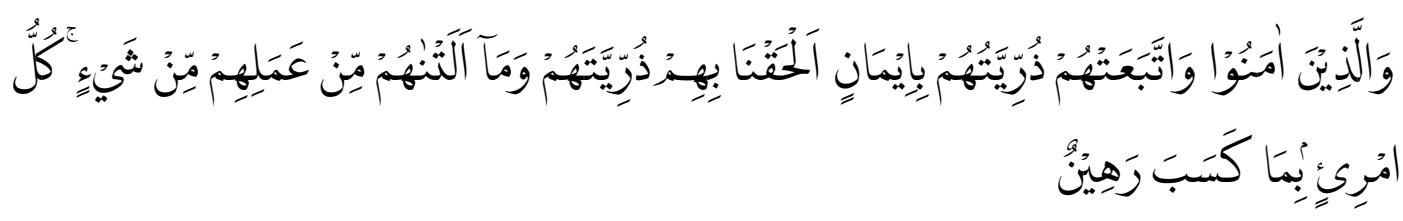

Dan orang-orang yang beriman, dan yang anak cucu mereka mengikuti mereka dalam keimanan, Kami hubungkan anak cucu mereka dengan mereka, dan Kami tiada mengurangi sedikitpun dari pahala amal mereka. tiap-tiap manusia terikat dengan apa yang dikerjakannya. (QS. ath-Thur/52: 21)

Mengenai efisiensi Allah berfirman:

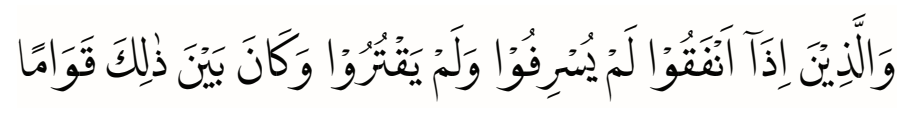

Dan orang-orang yang apabila membelanjakan (harta), mereka tidak berlebihan, dan tidak (pula) kikir, dan adalah (pembelanjaan itu) di tengah-tengah antara yang demikian. (QS. al-Furqan/25: 67)

Banyak sekali Hadis dan atsar sahabat Rasul yang cukup relevan untuk dipakai dalam manajemen. Para ulama salaf, maupun para ulama muta'akhirin telah menggunakan dalil-dalil itu dalam permasalahan imarah (manajemen), khilafah (pemerintahan), buyu (perdagangan) dan akhlak (etika). Semua cukup actual dan relevan sebagai dalil manajemen. Karena memang demikianlah halnya, bahwa semua kegiatan atau tindakan dan fungsi-fungsi manajemen itu, adalah pengaturan manusia (hablun minannas) yang merupakan salah satu perintah Allah sebagai pelaksana iman terhadapnya. Karena itu, pengetahuan manajemen perlu dikuasai oleh setiap Muslim, makin penting kedudukan seseorang di dalam masyarakat makin banyak permasalahan manajemen yang akan dihadapinya. Dengan demikian, pengetahuan manajemen tidak boleh dianggap asing, karena prinsipnya sudah tersedia di dalam al-Quran dan Hadis atau atsar sahabat Nabi. Tinggal kita menggalinya, dan menjembatani dengan prinsip-prinsip yang ada di dalam buku acuan yang tepat untuk 
masyarakat dan kebutuhan zaman ini. ${ }^{30}$

Di dalam al-Quran terdapat pokok-pokok ajaran mengenai hubungan manusia dengan Khaliknya, pokok-pokok ajaran hubungan antara manusia dengan manusia lainnya, prinsip ajaran akhlak (etika), bagaimana setiap manusia bertindak dan berbuat, ajaran bagaimana manusia mengatur tata kehidupan ini, seperti masalah kenegaraan, perniagaan, hukum, pertanahan, hukum keluarga dan pokok-pokok ajaran yang sekarang kita kenal dengan nama Manajemen. Jadi, di dalam al-Quran sebenarnya terdapat ajaran mengenai prinsip cara memimpin, prinsip mengenai cara mengatur penghidupan. Kesemua ajaran tersebut harus kita jadikan sebagai prinsip di dalam manajemen. Dengan demikian, ilmu manajemen itu bagi Islam bukan sesuatu yang baru, tetapi telah menjadi ajaran yang dipatuhi oleh setiap Muslim. Sebagian dari mereka sudah mempraktekkan dalam kehidupan, walaupun bukan dengan nama manajemen. ${ }^{31}$

Manajemen sebagai suatu ilmu dan teknik untuk mengurus atau mengelola tidak dapat lepas dari fungsi-fungsi dan kewajiban manusia yang telah ditetapkan Allah. Ketentuan Allah itu dapat kita lihat pada beberapa firman Allah yang memberikan petunjuk kepada kita untuk menempatkan masalah manajemen ini ke dalam fungsi dan kewajiban manusia yang telah di tetapkan Allah. ${ }^{32}$

Pendekatan manajemen yang dipakai dalam kajian Islam adalah sebagai berikut:

1. Fungsi manusia sebagai khalifah Allah

Islam menganggap bahwa kehadiran manusia di bumi ini adalah bukan karena "dosa pertama" Adam dan Hawa, tetapi kesengajaan dalam qadha Allah sebagai sunnatullah. Khalifah secara harfiah berarti wakil Allah di bumi. Ini menunjukan bahwa manusia adalah makhluk mulia karena memiliki ilmu, nafsu dan agama. Fungsi khalifah dalam mengurus dan mengatur hampir sama pengertiannya dengan pengertian kata bahasa Inggris to manage yang kemudian berkembang menjadi management, yang berarti pengurusan atau pengelolaan. Manajemen yang sedang kita bicarakan ini, merupakan tugas manusia yang imperatif, karena perintah Allah untuk dijalankan. ${ }^{33}$



Allah telah menjanjikan kepada orang-orang di antara kamu yang beriman dan yang mengerjakan kebajikan, bahwa Dia sungguh, akan menjadikan mereka berkuasa di bumi, sebagaimana Dia telah menjadikan orang-orang sebelum mereka berkuasa, dan sungguh, Dia akan meneguhkan bagi mereka dengan agama yang telah Dia ridai. Dan Dia benar-benar mengubah (keadaan) mereka, setelah berada dalam ketakutan

\footnotetext{
${ }^{30}$ Mochtar Effendy, p. 12-13.

${ }^{31}$ Mochtar Effendy, p. 14-15.

${ }^{32}$ Mochtar Effendy, p. 16.

${ }^{33}$ Mochtar Effendy, p. 18.
} 




menjadi aman sentosa. Mereka (tetap) menyembah-Ku dengan tidak mempersekutukan-Ku dengan sesuatu apa pun. Tetapi barangsiapa (tetap) kafir setelah (janji) itu, maka mereka itulah orang-orang yang fasik. (QS. An-Nur/24: 55)

2. Kewajiban manusia pengemban amanah Allah

Masyarakat adalah adalah amanat Allah kepada para pemimpin agar mereka dipimpin, dibimbing, dan dilindungi dari tindakan yang zalim atau sewenang-wenang. Demikian juga jabatan seseorang adalah amanah Allah dan rakyat, agar dipelihara dan dijalankan dengan sebaik-baiknya. Oleh karena itu, amanat harus ditunaikan, dan berdosa jika diabaikan dan disalahgunakan. Agar dapat melakukan amanat dengan baik berhasil guna, haruslah diketahui dasar-dasarnya, caranya, sistemnya, dan tekniknya. Semua itu termaktub di dalam ilmu manajemen. Menjalankan manajemen dengan baik adalah cara untuk menunaikan amanah. ${ }^{34}$

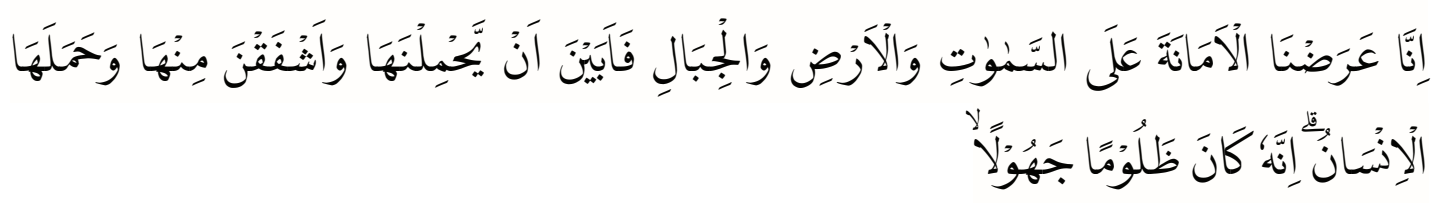

72. Sesungguhnya Kami telah menawarkan amanat kepada langit, bumi dan gununggunung; tetapi semuanya enggan untuk memikul amanat itu dan mereka khawatir tidak akan melaksanakannya (berat), lalu dipikullah amanat itu oleh manusia. Sungguh, manusia itu sangat zalim dan sangat bodoh, (QS. Al-Ahzab/33: 72)

3. Perjanjian manusia dengan Khaliknya

Menurut beberapa ulama, semasa manusia masih berada di alam arwah, telah mengadakan perjanjian dengan Allah. Di dalam perjanjian itu, manusia berjanji kepada Allah untuk meng-Esakan Allah, tidak mensyirikkan-Nya, akan selalu menunaikan semua perintah-Nya, akan melakukan yang ma'ruf (kebaikan) dan menjauhi kemungkaran. Perjanjian ini termaktub dalam QS. al-Araf/7: 172.

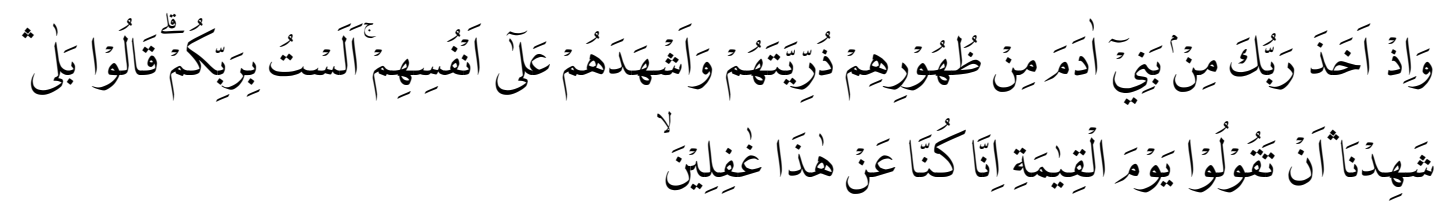

Dan (ingatlah) ketika Tuhanmu mengeluarkan dari sulbi (tulang belakang) anak cucu Adam keturunan mereka dan Allah mengambil kesaksian terhadap roh mereka (seraya berfirman), "Bukankah Aku ini Tuhanmu?" Mereka menjawab, "Betul (Engkau Tuhan kami), kami bersaksi." (Kami lakukan yang demikian itu) agar di hari Kiamat kamu tidak mengatakan, "Sesungguhnya ketika itu kami lengah terhadap ini." (QS. al-A'raf/7: 172).

Dengan demikian, semua permasalahan pengurusan, pengaturan dan pengelolaan

${ }^{34}$ Mochtar Effendy, p. 21-22. 
masyarakat, serta apa yang ada di planet ini, diperintahkan Allah kepada manusia, agar melaksanakan semua perintah-Nya, menjauhi larangan-Nya, serta mengatur dan mengelola sesuai dengan tuntunan-Nya, yaitu agama, akal, ilmu yang dibimbing hidayah Allah. Semua ini merupakan kewajiban manusia untuk menunaikan janji kepada Allah. ${ }^{35}$

4. Hakikat eksistensi manusia di atas bumi

Mendekati permasalahan manajemen dari sudut pandang kejadian manusia, atau dari sudut eksistensi manusia di muka bumi ini. Untuk memenuhi kebutuhan manusia, Allah menyediakan berbagai macam isi bumi berupa tanaman, hewan, bahan galian, air, laut dan isinya. Tetapi untuk memperoleh semua itu harus dengan usaha. Semuanya harus diusahakan, diolah, diatur, dan dilestarikan agar bisa direproduksi, karena disanalah manusia akan hidup dan akan mendapatkan penghidupan. ${ }^{36}$

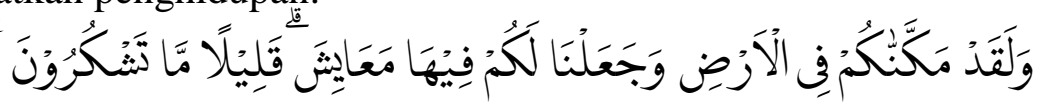

Dan sungguh, Kami telah menempatkan kamu di bumi dan di sana Kami sediakan (sumber) penghidupan untukmu. (Tetapi) sedikit sekali kamu bersyukur. (QS. alAraf/7: 10)

Sifat manusia diperoleh dari ajaran akhlak menjadi persyaratan bagi setiap manajer yang baik, karena menurut pola akhlak Islam pelaksanaan manajemen yang baik merupakan amal shaleh. Manajemen dengan fungsi-fungsi, unsur-unsurnya, kegiatan-kegiatan serta prosesnya, menempatkan manusia sebagai postulat dan fokusnya, dalam manajemen tidaklah dapat dilepaskan dari hukum Islam (syara). Hubungan manusia dengan Tuhannya termasuk dalam iman atau akidah, sedangkan hubungan muamalah terbagi dua yaitu maadiyah dan muamalah adabiyah. ${ }^{37}$

Agama Islam mewajibkan para pengusaha, atau penguasa untuk menegakkan keadilan, bekerja jujur, dan menyampaikan amanat demi terciptanya kesejahteraan umum. Untuk melaksanakan kewajiban-kewajiban itu, para pengusaha atau penguasa wajib menjalankan manajemen yang baik dan sehat. Manajemen yang baik harus memenuhi syarat yang tidak boleh ditinggalkan (conditio sine qua non) yang menjadi pengusaha atau penguasa wajib mempelajari manajemen. Apalagi jika mengingat prinsip-prinsip dan teknik yang terdapat di dalam al-Quran dan Hadis harus dipatuhi. Dengan demikian, manajemen harus dipelajari dan dilaksanakan dalam kehidupan sehari-hari. ${ }^{38}$

Prinsip dan teknik manajemen yang ada relevenasinya dengan ayat-ayat al-Quran atau Hadis, antara lain prinsip amar makruf nahyi munkar, kewajiban menegakkan kebenaran, kewajiban menegakkan keadilan, dan kewajiban menyampaikan amanat. ${ }^{39}$ Faktor yang wajib dipertimbangkan dalam menentukan penilaian dasar dan tujuan manajemen menurut Islam adalah hak asasi manusia, filsafat hak milik, hak dan kewajiban, kewajiban kemasyarakatan, cinta dan mencintai sesama manusia, dan keseimbangan dunia

\footnotetext{
${ }^{35}$ Mochtar Effendy, p. 24.

${ }^{36}$ Mochtar Effendy, 25-26.

${ }^{37}$ Mochtar Effendy, p. 31.

${ }^{38}$ Mochtar Effendy, p. 33.

${ }^{39}$ Mochtar Effendy, p. 40.
} 
dan akhirat. ${ }^{40}$

\section{F. Ciri-Ciri Manajemen Menurut Ajaran Islam}

Manajemen adalah proses niat, ikhtiar yang maksimal dan tawakal. Islam memandang esensi sebuah perbuatan adalah niatnya. Apabila niatnya baik maka akhirnya akan baik pula, begitu juga sebaliknya bila niatnya buruk maka hasilnya akan buruk pula. Sedangkan ikhtiar adalah adalah tindat lanjut dari niat yang telah dilaksanakan, atau bersamaan niat dengan tindakan. Ikhtiar dalam Islam harus maksimal dan terus menerus. Proses dalam manajemen adalah tawakal, yaitu goal atau tujuan sepenuhnya pada tuhan sambil terus menerus berikhtiar ${ }^{41}$

\section{Manajemen berdasarkan akhlak yang luhur}

Setiap Muslim dimanapun dia berada harus mempunyai akhlak yang luhur. al-Quran dan Hadis menjadi dasar dan sumber akhlak yang mulia. Oleh karena akhlak yang mulia membedakan antara orang Islam dan bukan Islam, maka tidak ada pilihan lain bagi setiap pemimpin atau seorang manajer Islam wajib memiliki, menghargai, mempraktekkan, akhlak ini. Perusahaan atau lembaga milik Muslim harus dikelola berdasarkan prinsip akhlak yang luhur. Penyelenggaraan manajemen harus pula berpedoman kepada akhlakul karimah. ${ }^{42}$

\section{Manajemen terbuka}

Fungsi dan tugas pimpinan atau manajer adalah memegang amanah, karena dia bukan mengurus atau mengelola harta benda miliknya sendiri, akan tetapi harta benda milik orang lain, yaitu harta pemegang saham atau rakyat. Oleh karena itu, ia harus mengelolanya dengan baik, dengan sehat, dan jujur. Dengan kata lain, ia harus mengelolanya menurut sistem manajemen terbuka. Jika seorang pemimpin atau manajer menerapkan sistem manajemen terbuka maka terpenuhilah tugasnya kepada Allah terutama mengenai zakat, kepada Pemerintah, mengenai pajak, dan kepada pemegang modal mengenai rugi laba yang sebenarnya. ${ }^{43}$

\section{Manajemen yang demokratis}

Sebagai akibat dari penerapan manajemen terbuka, pengelolaan suatu badan harus pula dijalankan secara demokratis. Manajemen demokratis artinya semua harus dimusyawarahkan bersama semua peserta, partisipan, dan pemegang saham. Mereka harus dapat diberi hak untuk menyampaikan pendapatnya. ${ }^{44}$

\section{Manajemen berdasarkan ilmiah}

Semua pemimpin atau manajer haruslah orang yang berilmu pengetahuan, karena dia yang merencanakan, atau mengurus atau mengelola setiap fungsi manajemen. Menurut ajaran Islam kepengurusan haruslah diselenggarakan secara ilmiah. Ilmu manajemen, baik

${ }^{40}$ Mochtar Effendy, p. 50.

${ }^{41}$ Fathul Aminudin Aziz, 'Memahami Manajemen Islam melalui Pendekatan Tafsir Metodologis,' Jurnal El-Jizya: Jurnal Ekonomi Islam, 6.2 (2018), 182.

${ }^{42}$ Mochtar Effendy, p. 280.

${ }^{43}$ Mochtar Effendy, p. 281.

${ }^{44}$ Mochtar Effendy, p. 283. 
yang bersifat teori maupun yang praktis atau merupakan keterampilan haruslah diuji dengan kebenaran ilmiah. ${ }^{45}$

\section{Manajemen berdasarkan tolong-menolong}

Manusia tidak dapat melepaskan diri dari masyarakat. Jika manusia bergerak sendirisendiri di alam ini, maka mereka akan dihancurkan oleh makhluk lain yang lebih kuat fisiknya. Dalam keadaan demikian, akan berlaku homo homini lopus yaitu makhluk saling memakan, yang kuat memakan yang lemah. Manusia dijadikan khalifah Allah di muka bumi karena kemampuan manusia melebihi kemapuan makhluk lain. ${ }^{46}$

\section{Manajemen berdasarkan perdamaian}

Perbedaan fungsi dan kedudukan sosial tidak boleh menimbulkan antagonistis dan kontradiktif, tetapi hal itu adalah akibat pembagian kerja yang merupakan rahmat Tuhan. Masing-masing menjalankan kewajiban dengan saling menghormati dan saling menghargai. Fungsi pemimpin adalah antara lain sebagai pemersatu. Persatuan dilakukan agar dapat bekerja sama dan tolong-menolong antara komponen tenaga kerja, modal dan manajemen. Persatuan harus diciptakan oleh para pemimpin atau menajer, sehingga tercipta organisasi produktif atau lembaga kemasyarakatan yang damai dan saling menguntungkan. Setiap pertentangan atau permusuhan harus diselesaikan dengan damai. ${ }^{47}$

\section{G. Analisis Pendekatan Manajemen dalam Pengkajian Islam}

Manajemen dewasa ini merupakan suatu disiplin ilmu yang banyak digunakan oleh masyarakat modern bahkan manajemen dijadikan sebagai wahana untuk membuat suatu kebudayaan dan peradaban yang baik, tertata dengan rapi, bertanggung jawab, teratur dalam hal admisnistrasi dan lain sebagainya. Kebudayaan sebagai alat yang kemudian mengembangkan produk yang disebut dengan manajemen. Manajemen dari masa ke masa masih menjadi primadona dan masih menjadi disiplin ilmu yang dapat memberikan nuansa yang berbeda terhadap situasi di masa sekarang dan masa yang akan datang.

Islam sebagai agama yang cinta damai, mendambakan suatu iklim yang teratur, menghormati perbedaan, menjunjung tinggi hak asasi manusia, dan sebagai agama yang cocok di manapun dan kapanpun. Islam sebagai sebuah agama, tentunya memiliki peran yang strategis terhadap eksistensi keberagamaannya itu. Dalam lingkup keterkaitan manajemen di dalam Islam sebetulnya sudah dimulai sejak masa lampu, apalagi manajemen itu sendiri termaktub di dalam al-Quran dan Hadis. Itu menandakan bahwa sebetulnya Islam dan manajemen sudah memiliki hubungan yang sangat mesra.

Islam memandang manajemen sebagai sebuah alat yang dapat digunakan untuk mengimplementasikan apa yang ada di dalam al-Quran dan Hadis, tidak heran bahwa manajemen digunakan sebagai disiplin ilmu untuk mendekati kajian Islam. Pendekatan tersebut kemudian menghasilkan temuan yang sangat luar biasa, manajemen ternyata mampu memberikan jawaban baik yang bersifat teori ataupun praktis. Islam sejatinya

\footnotetext{
${ }^{45}$ Mochtar Effendy, p. 287.

${ }^{46}$ Mochtar Effendy, p. 289.

${ }^{47}$ Mochtar Effendy, p. 292.
} 
merupakan salah satu pelopor terbentuknya atau adanya manajemen, hanya saja istilah yang digunakan saja yang berbeda. Islam telah mempraktekkan manajemen pada masa abad ke-7 sampe abad ke-14 dengan baik, hingga Islampun mengalami masa puncak kejayaan dan itu merupakan bukti nyata bahwa manajemen dalam pemerintahan, taktik perang dan lain sebagainya itu benar-benar berjalan dengan sangat baik. Manajemen sebagai barometer keberhasilan dan kejayaan Islam pada masa itu, dan harapannya juga untuk kebangkitan Islam.

Manajemen dapat digunakan sebagai pendekatan dalam mengkaji Islam. Manajemen sebagai sebuah ilmu juga memandang bahwa komponen, sistem pembentuk masyarakat, kekuatan moral, budi pekerti yang luhur di dalam Islam itu sangat cocok sekali jika dipadukan dengan fungsi dan prinsip manajemen. Manajemen sebagai sebuah terobosan dan jawaban untuk menjawab permasalahan yang tidak kunjung selesai dalam kemunduran Islam seperti sekarang. Pelaksanaan manajemen di kalangan umat Muslim sekarang sudah tidak lagi berjalan dengan baik dan sehat. Itu sebagai sebuah pukulan sungguh sangat menyakitkan, sebab manajemen itu sebenarnya bersumber dari Islam itu sendiri. Dalam perkembangannya, memang manajemen kemudian dikembangkan oleh bangsa Barat. Akan tetapi, kita tidak boleh menghindar dari manajemen produk Barat itu, justru hal yang harus dilakukan adalah mengadopsi sesuatu yang baik kemudian ini akan menjadikan Islam secara bertahap akan bangkit dari keterpurukan.

Krisis kepemimpinan, moral, etika, dan sebagainya juga sedikit banyak merupakan implikasi dari ketidakteraturan dan ketidakberdayaan umat Islam mengamalkan ilmu manajemen dengan baik. Adanya suatu permasalahan pajak, zakat, korupsi, kemiskinan dan beberapa hal lainnya itu karena manajemen tidak dilakukan dengan baik. Jika hal itu dijalankan dengan baik maka hal tersebut semestinya dapat dieleminir sedikit demi sedikit.

Pasang surut permasalahan manajemen yang kurang efektif telah melanda umat Islam semenjak abad ke-14. Ini ditandai dengan ketidakbenaran dalam mengelola, mengatur, terlalu egois, rakus, gila jabatan, korupsi, kolusi, nepotisme yang marak dan melanda dunia Islam. Kita sebagai generasi di era sekarang harus peduli terhadap permasalahan tersebut. Manajemen harus digunakan sebagai wahana untuk menumbuhkan kesadaran bahwa pengelolaan yang baik dan pengaturan yang cerdas akan memberikan nuansa yang kondusif, atau sebuah situasi yang akan memberikan dampak yang positif terhadap kemajuan Islam dan tentunya kemajuan terhadap tata kelola pemerintahan dalam Islam serta hal lain yang bermanfaat baik secara langsung atau tidak langsung.

\section{H. Simpulan}

Pengetahuan manajemen perlu dikuasai oleh setiap Muslim, makin penting kedudukan seseorang di dalam masyarakat makin banyak permasalahan manajemen yang akan dihadapinya. Dengan demikian, pengetahuan manajemen tidak boleh dianggap asing, karena prinsipnya sudah tersedia di dalam al-Quran dan Hadis atau atsar sahabat Nabi. Di dalam al-Quran terdapat pokok-pokok ajaran mengenai hubungan manusia dengan Khaliknya, pokok-pokok ajaran hubungan antara manusia dengan manusia lainnya, prinsip ajaran akhlak (etika), bagaimana setiap manusia bertindak dan berbuat, ajaran bagaimana manusia mengatur tata kehidupan ini, seperti masalah kenegaraan, perniagaan, hukum, 
pertanahan, hukum keluarga dan pokok-pokok ajaran yang sekarang kita kenal dengan nama Manajemen. Pendekatan manajemen dalam kajian Islam terdiri dari fungsi manusia sebagai khalifah Allah, kewajiban manusia pengemban amanah Allah, perjanjian manusia dengan Khaliknya, dan hakikat eksistensi manusia di atas bumi. Prinsip dan teknik manajemen yang ada relevenasinya dengan ayat-ayat al-Quran atau Hadis, antara lain prinsip amar ma'ruf nahyi munkar, kewajiban menegakkan kebenaran, kewajiban menegakkan keadilan, dan kewajiban menyampaikan amanat.

\section{Daftar Pustaka}

Aziz, Fathul Aminudin, Manajemen dalam Perspektif Islam (Cilacap: Pustaka El Bayan, 2017).

Aziz, Fathul Aminudin, 'Memahami Manajemen Islam melalui Pendekatan Tafsir Metodologis,' Jurnal El-Jizya: Jurnal Ekonomi Islam, 6.2 (2018).

Bafadal, Ibrahim, Manajemen Peningkatan Mutu Sekolah Dasar dari Sentralisasi Menuju Desentralisasi (Jakarta: Bumi Aksara, 2003).

Baharuddin, dan Moh. Makin, Manajemen Pendidikan Islam: Transformasi Menuju Sekolah/Madrasah Unggul (Malang: UIN Maliki Press, 2010).

Branine, Mohamed and David Pollard, 'Human resource management with Islamic management principles: A dialectic for a reverse diffusion in management', Personnel Review, 39.6 (2010), 712-727.

Effendy, Mochtar, Manajemen: Suatu Pendekatan Berdasarkan Ajaran Islam (Jakarta: Bhratara Karya Aksara, 1986).

Fattah, Nanang, Landasan Manajemen Pendidikan (Bandung: Remaja Rosdakarya, 2006).

Hasibuan, Malayu, Manajemen: Dasar, Pengertian dan Masalah (Jakarta: Bumi Aksara, 2006).

Manullang, Dasar-Dasar Manajemen (Yogyakarta: Gadjah Mada University Press, 2005).

Marno, dan Triyo Supriyatno, Manajemen dan Kepemimpinan Pendidikan Islam (Bandung: Refika Aditama, 2008).

Siagian, Sondang P. Teori Pengembangan Organisasi (Jakarta: Bumi Aksara, 2007).

Stoner, Freeman dan Gilbert, Manajemen (Jakarta: Prenhallindo, 1996).

Sudjana, Manajemen Program Pendidikan untuk Pendidikan Nonformal dan Pengembangan Sumber Daya Manusia (Bandung: Falah, 2004).

Suharsaputra, Uhar, Administrasi Pendidikan (Bandung: Refika Aditama, 2010).

Sulistyorini, Manajemen Pendidikan Islam: Konsep, Strategi dan Aplikasi (Yogyakarta: Teras, 2009).

Suwarto, Perilaku Keorganisasian (Yogyakarta: Atmajaya Press, 1999).

Syamsi, Ibnu, Pokok-Pokok Organisasi dan Manajemen (Jakarta: Rineka Cipta, 1994).

Terry, George R., Asas-Asas Manajemen (Bandung: Alumni, 2006). 


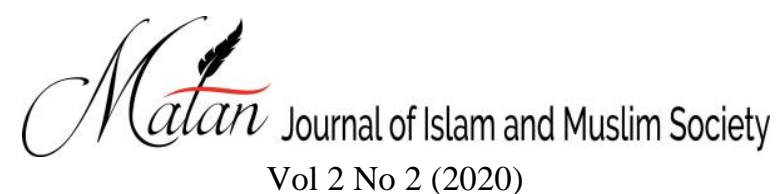

Tunggal, Amin Widjaja, Manajemen Suatu Pengantar (Jakarta: Rineka Cipta, 2002).

Usman, Husaini, Manajemen: Teori. Praktik, dan Riset Pendidikan (Jakarta: Bumi Aksara, 2011). 